PENENTUAN NASABAH PENERIMA REWARD PRODUK GOLD DENGAN METODE SIMPLE ADDITIVE WEIGHTING (SAW) STUDI KASUS : PT. PINJAM INDONESIA

Riki Ruli A. Siregar; Faizal Fachrurrozi

IMPLEMENTASI METODE BACKWARD CHAINING PADA DATA WAREHOUSE DAOP 1 JAKARTA PT. KAI (PERSERO) Rakhmat Arianto; Chandra Bagus Sugiarto

IMPLEMENTASI METODE DETEKSI TEPI CANNY PADA OBJEK SEBAGAI MODEL KEAMANAN APLIKASI PADA SMARTPHONE ANDROID

Abdul Haris; Andi Prasetyo

ANALISA DATA DAN PERANCANGAN APLIKASI SERVICE PELANGGAN PT. JNE UNTUK PENINGKATAN KUALITAS LAYANAN

Dewi Arianti Wulandari; Sonny Syahrindra Putra

JARINGAN AD-HOC VEHICULAR (VANET) : TINJAUAN TENTANG ARSITEKTUR, KARAKTERISTIK, APLIKASI, DAN PROTOKOL MEDIUMACCESS CONTROL (MAC)

Rosida Nur Aziza

PERANCANGAN APLIKASI PENJADWALAN MATA KULIAH MENGGUNAKAN METODE CONSTRAINT PROGRAMMING Syam Gunawan

RANCANGAN TATA KELOLA PEREMAJAAN RUANG KELAS DIREKTORAT PEMBINAAN SEKOLAH DASAR

Ratna Mutu Manikam; Purwanto

PENGEMBANGAN AMORIK MENGGUNAKAN METODE GARIS SINGGUNG TERHADAP DUA LINGKARAN DAN PERSAMAAN KURVA BEZIER ORDE DUA.

Darma Rusjidi

OPTIMALISASI PENGAMBILAN KEPUTUSAN PENILAIAN KINERJA DOSEN PADA PERGURUAN TINGGI ISLAM XYZ MENGGUNAKAN AHP (ANALYTICAL HIERARCHY PROCESS)

Rahma Farah Ningrum

PENGAMANAN SMS PADA TELEPON SELULER BERBASIS ANDROID MENGGUNAKAN ALGORITMA TRIPLE DES Raka Yusuf; $M$. Rival Suheri

APLIKASI LATIHAN SOAL UJIAN TEORI SURAT IZIN MENGEMUDI BERBASIS WEB Harni Kusniyati; Raka Yusuf; Andri Setiawan

RANCANG BANGUN SIMULASI TERJADINYA LISTRIK DENGAN SUMBER DAYA SAMPAH BERBASIS MULTIMEDIA (STUDI KASUS : TPST BANTAR GEBANG)

Yasni Djamain; Ika Fitriyani Putri

\begin{tabular}{|c|c|c|c|c|c|c|}
\hline \multirow{2}{*}{ 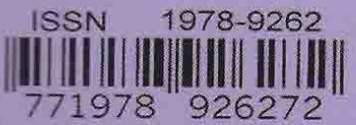 } & \multicolumn{6}{|c|}{ SEKOLAH TINGGI TEKNIK - PLN (STT-PLN) } \\
\hline & PETIR & VOL. 9 & No. 1 & HAL. 1 - 87 & JAKARTA, MARET 2016 & ISSN $1978-9262$ \\
\hline
\end{tabular}




\title{
OPTIMALISASI PENGAMBILAN KEPUTUSAN PENILAIAN KINERJA DOSEN PADA PERGURUAN TINGGI ISLAM XYZ MENGGUNAKAN AHP (ANALYTICAL HIERARCHY PROCESS)
}

\author{
Rahma Farah Ningrum \\ Program Studi Teknik Informatika Sekolah Tinggi Teknik PLN Jakarta \\ rahma_farah@yahoo.com
}

\begin{abstract}
ABSTRAK
Dalam suatu proses pengambilan keputusan, para pengambil keputusan seringkali dihadapkan pada berbagai masalah yang bersumber dari beragamnya kriteria. Terkait dengan hal tersebut, Analytical Hierarchy Process (AHP) dapat digunakan untuk menyelesaikan masalah tersebut. Salah satunya adalah penilaian kinerja dosen pada suatu perguruan tinggi islam yang bersandar pada kriteria integritas, kompetensi profesional, dan performance. Demi efektifitas kerja suatu institusi perguruan tinggi, diperlukan suatu perangkat lunak pendukung keputusan seperti EC (Expert Choice) yang dapat mengolah data untuk dapat merekomendasikan sebuah keputusan berkenaan dengan kinerja dosen-dosen yang akan berpengaruh terhadap kenaikan golongan maupun gaji.
\end{abstract}

Kata kunci : Analytical Hierarchy Process (AHP), Sistem Pendukung keputusan, Kinerja, Expert Choice

\begin{abstract}
In a decision-making process, decision makers are often faced with various problems that come from the diversity criteria. Related to this, the Analytical Hierarchy Process (AHP) can be used to resolve such issues. One is the assessment of islamic university lecturer performance who rely on the criteria of integrity, professional competence, and performance. For the sake of effectiveness of an islamic higher education institution, required a software decision support system such as EC (Expert Choice) that can process data in order to recommend a decision regarding the performance of lecturers that will affect the class and salary increment.
\end{abstract}

Keywords: Analytical Hierarchy Process (AHP), decision Support System, Performance, Expert Choice

\section{PENDAHULUAN}

\subsection{Latar Belakang}

Menurut undang-undang nomor 14 tahun 2005, pasal 1 ayat 2, Dosen adalah pendidik profesional dan ilmuwan dengan tugas utama mentransformasikan, mengembangkan, dan menyebarluaskan ilmu pengetahuan, teknologi, dan seni melalui pendidikan, penelitian, dan pengabdian kepada masyarakat. Sementara Guru besar atau profesor yang selanjutnya disebut profesor adalah jabatan fungsional tertinggi bagi dosen yang masih mengajar di lingkungan satuan pendidikan tinggi (Undang-undang nomor 14 tahun 2005, pasal 1 ayat 3 ).

Dosen adalah pendidik profesional yang mempunyai tugas, fungsi, dan peranan penting dalam mencerdaskan kehidupan bangsa. Dosen yang profesional diharapkan mampu berpartisipasi dalam pembangunan nasional untuk mewujudkan insan Indonesia yang bertaqwa kepada Allah SWT, unggul dalam ilmu pengetahuan dan teknologi, memiliki jiwa estetis, etis, berbudi luhur, dan berkepribadian. Tidaklah berlebihan kalau dikatakan bahwa masa depan masyarakat, bangsa, negara, sebagian besar di tentukan oleh guru/dosen. Oleh sebab itu, profesi dosen perlu di tingkatkan dan di kembangkan secara terus menerus dan proporsional menurut jabatan fungsional dosen. Maka dari itu di perlukan penilaian kinerja dosen yang menjamin terjadinya proses pembelajaran yang berkualitas di setiap perguruan tinggi.

Penilaian-penilaian tersebut berdasarkan pada kriteria-kriteria yang telah ditetapkan pada setiap perguruan tinggi. Hasil dari penilaian tersebut dapat digunakan sebagai bahan pertimbangan untuk mengambil sebuah keputusan apakah layak atau tidak layak seorang dosen mendapatkan promosi jabatan baik struktural maupun fungsional, kenaikan gaji dan tunjangan.

Jika proses pengambilan keputusan ini dibantu oleh sebuah aplikasi sistem pendukung keputusan seperti Expert Choice, diharapkan subyektifitas dalam pengambilan keputusan dapat dikurangi sehingga perguruan tinggi akan mendapatkan dosen dengan ilmu dan dedikasi yang terbaik.

\subsection{Rumusan Masalah}

Rumusan masalah pada penulisan ini adalah :

1) Bagaimana menerapkan metode AHP (Analytical Hierarchy Process) pada proses penilaian kinerja dosen ?

2) Kriteria dan sub kriteria apa saja yang diperlukan untuk menentukan alternatif 
pengambilan keputusan dalam penilaian kinerja dosen pada perguruan tinggi $X Y Z$ ?

3) Kriteria dan sub kriteria apa yang menjadi prioritas utama yang digunakan dalam menilai kinerja dosen?

\subsection{Tujuan Penelitian}

Penulisan ini bertujuan untuk :

1) Memperoleh gambaran kriteria dan sub kriteria yang sering dijadikan acuan dalam menilai kinerja dosen.

2) Untuk mengetahui kriteria dan sub kriteria yang menjadi prioritas dalam menilai kinerja dosen.

\section{LANDASAN TEORI}

\subsection{Teori Sistem Pendukung Keputusan}

Sistem Pendukung Keputusan (Decision Support System) merupakan bagian dari Sistem Informasi Berbasis Komputer (CBIS). Konsep Sistem Pendukung Keputusan (Decision Support System) dimulai pada akhir tahun 1960-an dengan timesharing komputer. Untuk pertama kalinya seseorang dapat berinteraksi langsung dengan komputer tanpa harus melalui spesialis informasi. Baru pada tahun 1971, istilah DSS diciptakan oleh G. Anthony Gorry dan Michael S. Scott Morton dalam ([MCLEOD 2004], 279). Mereka mendefinisikan Sistem Pendukung Keputusan (SPK) sebagai suatu sistem interaktif berbasis computer yang dapat membantu para pengambil keputusan dalam menggunakan data dan model untuk memecahkan persoalan yang bersifat tidak terstruktur.

Menurut Moore and Chang, Sistem Pendukung Keputusan dapat digambarkan sebagai sistem yang berkemampuan mendukung analisis ad hoc data, dan pemodelan keputusan, berorientasi keputusan, orientasi perencanaan masa depan, dan digunakan pada saat-saat yang tidak biasa [Wikipedia1 2009]. Sedangkan menurut Turban (1998) Sistem Pendukung Keputusan (Decision Support System) merupakan alat manajemen yang terdiri dari komponen basis data, basis model dan user interface yang berbasis komputer yang dapat digunakan untuk memecahkan masalah dan membantu tugas-tugas pengambilan keputusan. DSS mendukung pengambilan keputusan kompleks dengan penekanan pada efektifitas

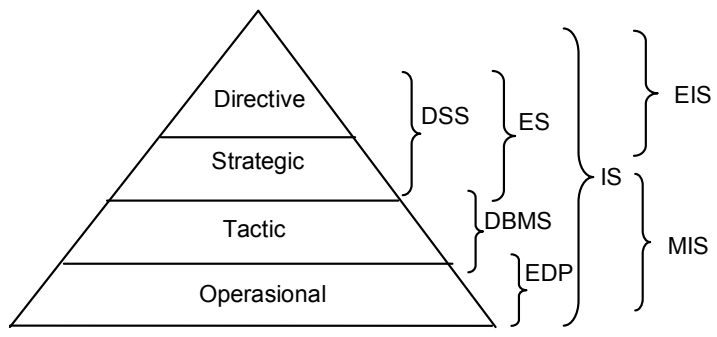

Gambar 2.1 Posisi Sistem Pendukung Keputusan (DSS) pada Sistem Informasi (IS) ([MARIMIN 2004],118)

2.2 Metode Pengambilan Keputusan dengan Analytical Hierarchy Process (AHP).
Dalam suatu proses pengambilan keputusan, para pengambil keputusan seringkali dihadapkan pada berbagai masalah yang bersumber dari beragamnya kriteria. Sebagai contoh praktis, Pemerintah Daerah (Pemda) sering menghadapi kesulitan dalam menentukan prioritas dalam proses pengambilan keputusan dan kebijakan di daerah. Terkait dengal hal tersebut, Analytic Hierarchy Process (AHP) dapat digunakan untuk menyelesaikan masalah tersebut.

AHP dikembangkan di Wharton School of Business oleh Thomas Saaty pada tahun 1970-an. Pada saat itu Saaty merupakan profesor di Wharton School of Business. Pada tahun 1980, Saaty akhirnya mempublikasikan karyanya tersebut dalam bukunya yang berjudul Analytic Hierarchy Process. AHP kemudian menjadi alat yang sering digunakan dalam pengambilan keputusan karena AHP berdasarkan pada teori yang merefleksikan cara orang berpikir. Dalam perkembangannya, AHP dapat digunakan sebagai model alternatif dalam menyelesaikan berbagai macam masalah, seperti memilih portofolio dan peramalan. Dalam kehidupan sehari-hari, manusia sering menghadapi kondisi untuk melakukan pengambilan keputusan dengan segera. Umumnya kita juga telah memikirkan beberapa alternatif solusi, dengan berbagai argumen pro dan kontra, AHP dapat memfasilitasi evaluasi pro dan kontra tersebut secara rasional.

\subsection{Teori Penilaian Kinerja}

Penilaian kinerja karyawan telah dilakukan oleh berbagai organisasi sejak berabad-abad. Meskipun sistem penilaian kinerja telah diperdebatkan oleh masyarakat luas, namun secara keseluruhan bisa dilihat bahwa penilaian kinerja merupakan bagian yang tidak terpisahkan dari kehidupan organisasi. Longenecker dan Fink (1999) mengutip beberapa alasan bahwa penilaian kinerja formal dalam organisasi diperlukan secara benar untuk proses kenaikan gaji, promosi, penurunan pangkat (Rafikul Islam, 2005).

Disisi lain penilaian kinerja merupakan sebagian penting dari budaya organisasi dan diperlukan untuk menilai kemajuan menuju tujuan organisasi (Daley, 1993 dan Farr, 1983). Selain itu definisi yang lain bahwa penilaian prestasi kerja merupakan prosedur yang formal dilakukan di dalam organisasi untuk mengevaluasi Karyawan dan sumbangan serta kepentingan bagi Karyawan (Dale Yoder, 1981. ; Rafikul Islam, 2005).

Karena penilaian kinerja merupakan hal yang sangat penting maka harus hati-hati dalam menerapkan penilaian kinerja. Sistem penilaian kinerja yang tidak efektif akan membawa banyak masalah termasuk rendah moral, penurunan produktivitas karyawan, yang mengurangi antusiasme karyawan dan dukungan untuk organisasi (Somerick, 1993;Rafikul Islam, 2005).

Contoh unsur-unsur yang dinilai adalah kesetiaan, prestasi kerja, kejujuran, kedisiplinan, kreativitas, kerja sama, kepemimpinan, kepribadian, prakarsa, kecakapan dan tanggung jawab (Hasibuan Malayu SP, 2009). 
Pada dasarnya Penilaian kinerja adalah menilai rasio hasil kerja nyata dengan standar kualitas maupun kuantitas yang dihasilkan setiap karyawan. Menetapkan kebijaksanaan berarti karyawan akan dipromosikan, didemosikan, dan atau balas jasanya dinaikkan. (Hasibuan, 2009).

\subsection{Penyelesaian AHP dengan Aplikasi Expert} Choice.

Expert Choice 2000 merupakan perangkat lunak yang dapat digunakan untuk perhitungan pemecahan persoalan dengan AHP. Pada penulisan tesis ini, digunakan analisis ganda dengan perhitungan sesuai formula dan juga perhitungan dengan menggunakan aplikasi Expert Choice 2000. Tujuan dilakukan analisis ganda ini adalah untuk membandingkan dan membuktikan analisa perhitungan penulis sesuai dengan aplikasi expert choice yang sudah teruji kehandalannya.

\subsection{Tinjauan Studi}

Beberapa penelitian yang pernah dilakukan dengan pendekatan Analytical Herarchy Process (AHP) antara lain:

1) "Strategi IT Disaster Recovery Plan pada Core Banking System Dengan Pendekatan Analytical Hierarchy Process : Studi Kasus pada PT. Bank Mega Tbk [DYAH 2008]. Tujuan dari penelitian tersebut adalah untuk memberikan rekomendasi pengambil keputusan mengenai strategi IT penerapan DRP (Disaster Recovery Plan) dalam mengantisipasi kejadian yang tidak di inginkan seperti bencana alam (banjir, gempa bumi, tsunami, dII), pemadaman listrik oleh PLN dan serangan virus pada sistem operasi computer yang mengakibatkan proses bisnis suatu perusahaan mengalami kelumpuhan atau dengan kata lain tidak dapat beroperasi secara normal ketika terjadi bencana.

2) "Strategi Proses Migrasi Proprietary Software ke Open Source Software di Perusahaan Dengan Pendekatan Analytical Hierarchy Process (AHP)", Studi Kasus : SGU, Tangerang [ERIKSON 2008]. Tujuan dalam penelitian tersebut adalah untuk memberikan rekomendasi pengambil keputusan yang telah dibobotkan berdasarkan tingkat kepentingan (urgency) perusahaan sebelum dan pada saat melakukan migrasi pemanfaatan aplikasi dari proprietary software ke open source software sehingga diharapkan fungsi SI/TI sebagai pendukung dan penggerak proses bisnis dapat ditingkatkan untuk memperoleh keunggulan kompetitif perusahaan. Pemanfaatan SI/TI dalam meningkatkan kinerja IT secara optimal, akan memberikan keuntungan bisnis yang optimal pula. Dan melalui penelitian ini juga diperoleh gambaran bahwa tidak selalu investasi IT yang semakin besar akan memberikan keuntungan bisnis yang semakin besar pula, yang terpenting adalah bagaimana memaksimalkan investasi IT yang dilengkapi dengan analisa dan langkah-langkah strategis IT untuk sustainability perusahaan.

3) "Sistem Pendukung Keputusan Dalam Menentukan SMK Berprogram Studi Teknologi Informasi Yang Favorit Berdasarkan Pendekatan Analytical Hierarchy Process (Ahp) Studi Kasus : Dinas $\mathbf{P} \& \mathbf{K}$ Kotamadya Tangerang [RAHMA 2009]. Tujuan dalam penelitian tersebut adalah untuk Memperoleh informasi sementara/pada saat ini mengenai SMKN Berprogram Studi TI yang Favorit di kotamadya Tangerang, apa saja yang menjadi kriteria dalam menentukan suatu program studi di sekolah negeri di katakan favorit dan rekomendasi yang dapat diambil oleh pemegang kebijakan di daerah berkaitan dengan alokasi dana pengembangan bagi pendidikan di sekolah bersangkutan.

\section{METODE PENELITIAN}

\subsection{Kerangka Pemikiran}

Secara umum, pemikiran dalam penulisan ini tersaji dalam diagram alir kerangka pemikiran dibawah ini. Diagram tersebut memperlihatkan tahap-tahap proses penelitian yang harus dilakukan sampai pada tahap penyusunan laporan.

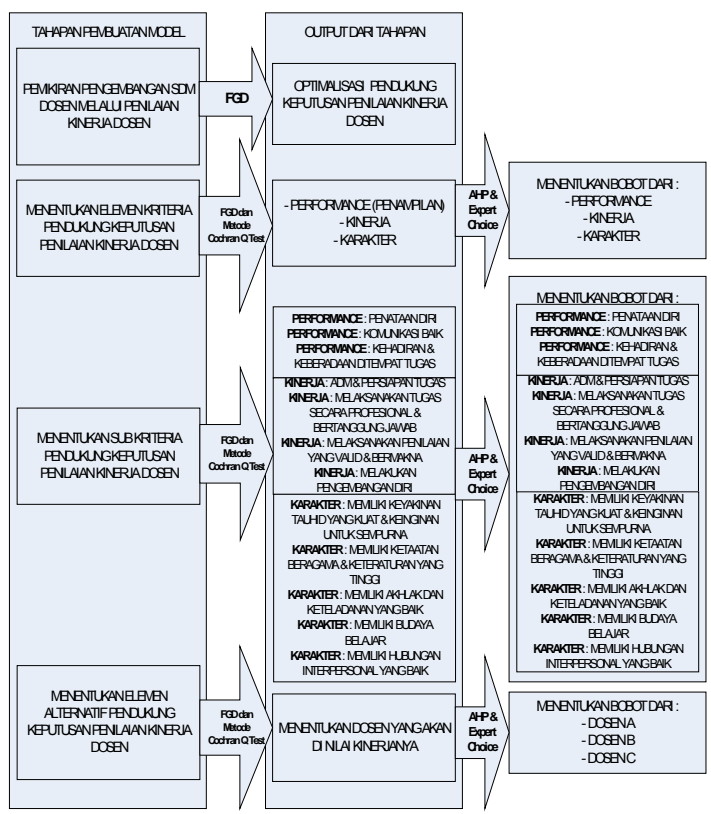

Gambar 3-1 Kerangka Pemikiran

Kerangka pemikiran di atas menggambarkan proses pengambilan keputusan dalam penilaian kinerja dosen. Bagian penting dari penelitian ini adalah proses penentuan kriteria, sub kriteria dan alternatif strategis. Agar tidak terjadi inkonsistensi pada pembuatan model, maka dilakukan Focus Group Discussion (FGD) dengan para responden untuk menentukan tahapan pembuatan model yang valid dengan elemen-elemen signifikan yang berpengaruh pada model. Hasil yang diperoleh dari 
kuesioner FGD ini adalah kriteria-kriteria signifikan, sub-sub kriteria signifikan, dan alternatif-alternatif signifikan yang membentuk proses pengambilan keputusan.

Pengolahan data responden dalam FGD ini, diolah dengan menggunakan metode statistik conchrant $Q$ test. Metode ini menggunakan pendekatan iterasi di mana atribut-atribut yang tidak layak melalui proses analisis dieliminasi sehingga atribut-atribut yang tertinggal benar-benar atribut-atribut yang penting untuk diteliti.

\subsection{Hipotesis}

Dengan diterapkan penulisan yang berjudul

"Optimalisasi Pengambilan Keputusan Penilaian Kinerja Dosen Pada Perguruan Tinggi XYZ dengan Menggunakan Metode AHP" maka diambil hipotes direksional sebagai berikut:

$\mathrm{H}_{1}=$ Diduga kriteria Performance (penampilan), Kinerja dan Karakter merupakan kriteria yang menentukan dalam penilaian kinerja dosen.

$\mathrm{H}_{2}=$ Diduga sub kriteria untuk kriteria :

- Performance : Penataan diri, Komunikasi baik dan Kehadiran dan keberadaan ditempat tugas.

- Kinerja : Administrasi \& Persiapan Tugas, Melaksanakan Tugas secara professional \& bertanggung jawab, Melaksanakan Penilaian yg valid \& bermakna dan Melakukan pengembangan Diri .

- Karakter : Memiliki keyakinan Tauhid yg kuat \& keinginan untuk sempurna, Memiliki ketaatan beragama \& keteraturan yg tinggi, Memiliki akhlak \& keteladanan yg baik, Memiliki budaya belajar, dan Memiliki Hubungan Interpersonal yg baik.

$\mathrm{H}_{3}=$ Diduga kriteria kinerja dan sub kriteria Kehadiran dan keberadaan ditempat tugas, Melaksanakan Tugas secara professional \& bertanggung jawab, dan Memiliki akhlak \& keteladanan yg baik adalah kriteria dan sub kriteria yang menjadi prioritas utama dalam menentukan penilaian kinerja dosen.

\subsection{Sampling/Metode Pemilihan Sampel}

Dalam penulisan ini, data dan informasi di kumpulkan dari para responden dengan menggunakan teknik wawancara dan pengamatan yang dilakukan di Perguruan Tinggi Islam. Diharapkan setelah melakukan penelitian ini, Para pemegang kebijakan di perguruan tinggi yang bersangkutan dapat menetapkan langkah-langkah untuk meningkatkan mutu pendidikan khususnya pada dosen berdasarkan peringkat pembobotan yang diperoleh.

\subsection{Metode Pengumpulan data}

Proses pengumpulan data dimulai dengan mencari data primer dan sekunder, dengan melakukan survei sesuai dengan kebutuhan dan kondisi yang ada. Setelah data yang diperoleh memadai, maka penulis melakukan analisa kebutuan dan membuat model dalam bentuk kuesinoner. Selanjutnya kuesioner diberikan kepada beberapa responden yang terkait, yaitu kepala jurusan, rekan kerja dan mahasiswa.

Tahap akhir dari penelitian ini adalah melakukan pengolahan data yang ada dengan pendekatan proses hierarki analitis (AHP) untuk merumuskan masalah dan mendapatkan peringkat alternatif-alternatif yang akan dilakukan untuk menilai kinerja dosen.

\subsection{Instrumentasi}

Pengumpulan data dilakukan menggunakan kuesioner melalui dua tahap. Pada tahap awal dilakukan kuesioner dengan pendekatan Focus Discussion Group (FGD), untuk menentukan elemen-elemen yang signifikan pada masingmasing level dimulai dari level I untuk penentuan kriteria, level II untuk penentuan sub kriteria, dan level III untuk penentuan alternatif pilihan. Pengolahan data kuesioner ini dengan menggunakan uji cochrant $Q$, sehingga elemenelemen menjadi signifikan berdasarkan data responden. Pada tahap selanjutnya dibuat kuesioner untuk perbandingan berpasangan di antara elemen pada masing-masing level. Diagram hierarki ditunjukkan pada gambar 3-2 dibawah ini.

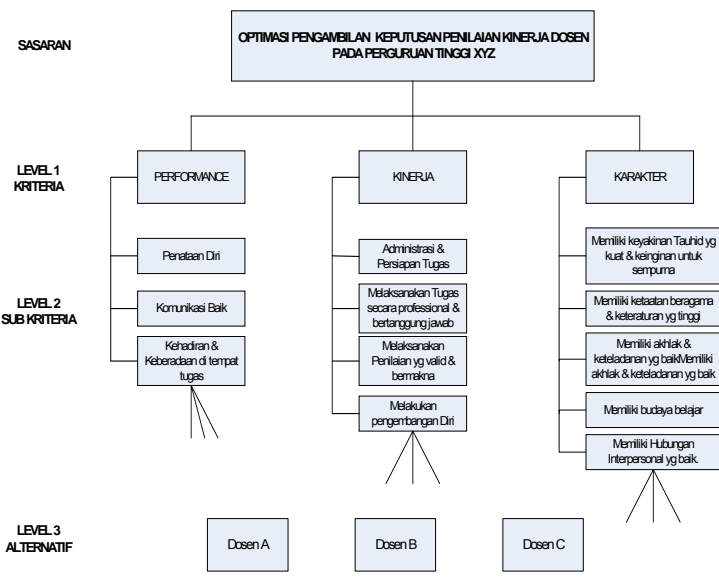

Gambar 3-2 Diagram hierarki dan keputusan dengan pendekatan AHP

Kuesioner yang telah dirancang selanjutnya digunakan pada tahap wawancara dengan responden yang terkait. Data kuesioner diolah dengan pendekatan proses hierarki analitis (AHP), dengan menggunakan manipulasi matrik. Sebagai analisa pembanding digunakan aplikasi Expert Choice 2000.

\section{PEMBAHASAN}

\subsection{Hasil Pengolahan Data dengan Expert Choice 2000.}

Setelah melalui proses pengisian kuesioner oleh beberapa responden ahli, dan melalui perhitungan geometris penggabungan data responden diperoleh nilai bobot alternatif seperti yang disajikan pada grafik berikut: 


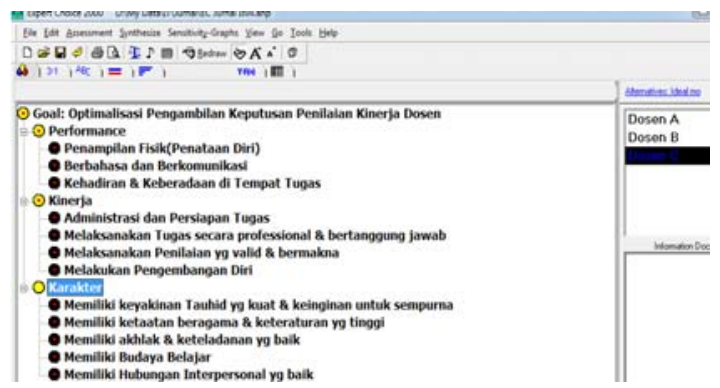

Gambar 4-1 Hierarchy AHP pada Expert Choice

\subsubsection{Hasil Prosentase masing-masing kriteria Penilaian Kinerja Dosen.}

Analisis pendapat gabungan para responden menunjukkan bahwa kriteria "Kinerja" (nilai bobot 0,637 atau sebanding dengan $63,7 \%$ dari total kriteria) merupakan kriteria yang paling penting, yang mempengaruhi suatu pengambilan keputusan dalam penilaian kinerja dosen.

Berikut ini disajikan bobot masing-masing kriteria yang mempengaruhi proses pengambilan keputusan.

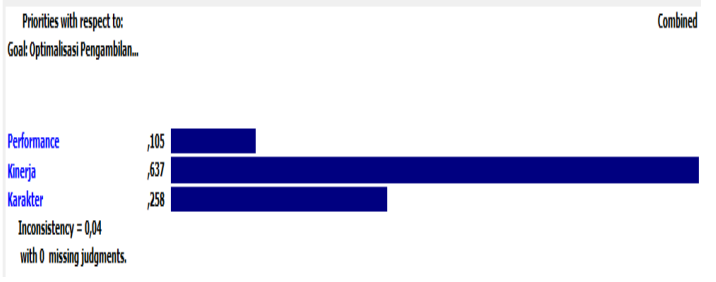

Gambar 4-2 Hasil Prosentase masing-masing kriteria penilaian dosen

\subsubsection{Nilai Bobot Prioritas sub kriteria berdasarkan Performance}

Turunan dari kriteria performace memiliki 3 (tiga) sub kriteria, yaitu: 1) sub kriteria Penampilan Fisik(Penataan Diri); 2) sub kriteria Berbahasa dan Berkomunikasi; dan 3) sub kriteria Kehadiran \& Keberadaan di Tempat Tugas.

Dari ketiga sub kriteria ini, sub kriteria yang paling utama dinilai oleh responden ahli adalah sub kriteria " Kehadiran \& Keberadaan di Tempat Tugas" (nilai bobot 0,637 atau $63,7 \%$ dari total sub kriteria yang ada).

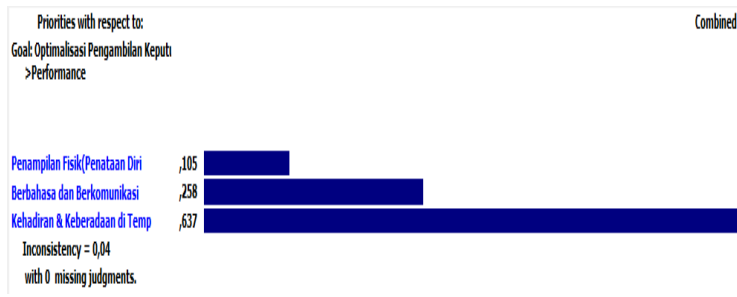

Gambar 4-3 Nilai Bobot Prioritas sub kriteria berdasarkan Performance

4.1.3. Nilai bobot prioritas sub kriteria berdasarkan kriteria kinerja

Kriteria kinerja memiliki 4 (empat) sub kriteria terkait yang menjadi turunannya, antara lain: 1) sub kriteria Administrasi \& Persiapan Tugas; 2) sub kriteria Melaksanakan Tugas secara professional \& bertanggung jawab; 3) sub kriteria Melaksanakan Penilaian yg valid \& bermakna; dan 4) sub kriteria Melakukan pengembangan Diri.

Berdasarkan pendapat responden ahli sub kriteria "Melaksanakan Tugas secara professional \& bertanggung jawab" merupakan sub kriteria dengan prioritas tertinggi yang memiliki kedekatan di banding tiga sub kriteria lainnya (nilai bobot 0,573 atau sebanding dengan $57,3 \%$ dari total sub kriteria yang ada). Kemudian prioritas sub kriteria berikutnya dari yang tertinggi ke prioritas terendah adalah sub kriteria Melaksanakan Penilaian yg valid \& bermakna (nilai bobot 0,264 atau sebanding dengan $26,4 \%$ dari total sub kriteria), diikuti dengan sub kriteria "Melakukan pengembangan Diri" (nilai bobot 0,105 atau sebanding dengan $10,5 \%$ dari total sub kriteria) sementara prioritas keterkaitan yang terkecil dari kriteria kinerja adalah sub kriteria Administrasi \& Persiapan Tugas (nilai bobot 0,057 atau sebanding dengan $5,7 \%$ dari total sub kriteria).

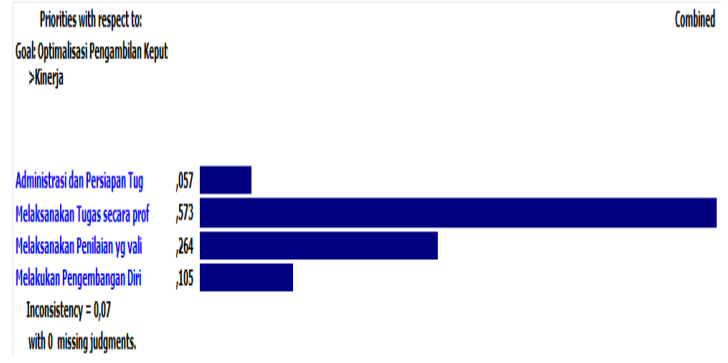

Gambar 4-4 Nilai Bobot Prioritas sub kriteria berdasarkan Kinerja

4.1.4. Nilai bobot prioritas sub kriteria berdasarkan kriteria karakter

Kriteria karakter memiliki 5 (lima) sub kriteria terkait yang menjadi turunannya, yaitu: 1) Memiliki keyakinan Tauhid yg kuat \& keinginan untuk sempurna; 2) Memiliki ketaatan beragama \& keteraturan yg tinggi; 3) Memiliki akhlak \& keteladanan yg baik; 4) Memiliki budaya belajar; dan 5) Memiliki Hubungan Interpersonal yg baik.

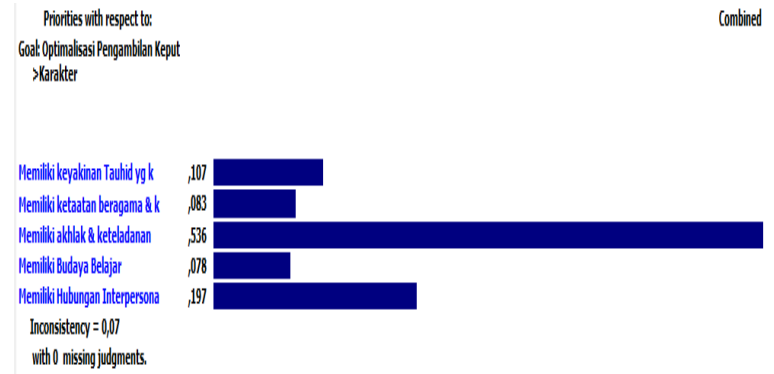

Gambar 4-5 Nilai Bobot Prioritas sub kriteria berdasarkan Karakter

Berdasarkan persepsi responden ahli, sub kriteria "Memiliki akhlak \& keteladanan yg baik" merupakan sub kriteria dengan prioritas tertinggi 
yang memiliki kedekatan di banding empat sub kriteria lainnya (nilai bobot 0,536 atau sebanding dengan $53,6 \%$ dari total sub kriteria yang ada). Kemudian prioritas sub kriteria berikutnya dari yang tertinggi ke prioritas terendah adalah sub kriteria Memiliki Hubungan Interpersonal yg baik (nilai bobot 0,197 atau sebanding dengan $19,7 \%$ dari total sub kriteria), diikuti dengan sub kriteria "Memiliki keyakinan Tauhid yg kuat \& keinginan untuk sempurna" (nilai bobot 0,107 atau sebanding dengan $10,7 \%$ dari total sub kriteria) sementara sub kriteria yang menjadi prioritas ke empat adalah "Memiliki ketaatan beragama \& keteraturan yg tinggi " dengan nilai bobot 0,083 atau sebanding dengan $8,3 \%$ dan prioritas keterkaitan yang terkecil dari kriteria karakter adalah sub kriteria Memiliki Budaya Belajar dengan nilai bobot 0,078 atau sebanding dengan $7,8 \%$ dari total sub kriteria.

4.2 Landasan Alternatif yang menjadi prioritas penentuan pengambilan keputusan dalam penilaian kinerja dosen ditinjau dari elemen sub kriteria dan kriteria.

Pada penelitian ini terdapat 12 (dua belas) sub kriteria dan kriteria yang mempengaruhi prioritas alternatif strategis dalam skala lokal yang diperoleh dari pengolahan data responden ahli, yaitu:

1) Nilai bobot alternatif strategis berdasarkan kriteria-sub kriteria : Performace > Penampilan Fisik (Penataan Diri).

2) Nilai bobot alternatif strategis berdasarkan kriteria-sub kriteria : Performace > Berbahasa dan Berkomunikasi.

3) Nilai bobot alternatif strategis berdasarkan kriteria-sub kriteria : Performace $>$ Kehadiran $\&$ Keberadaan di Tempat Tugas.

4) Nilai bobot alternatif strategis berdasarkan kriteria-sub kriteria : Kinerja > Administrasi \& Persiapan Tugas.

5) Nilai bobot alternatif strategis berdasarkan kriteria-sub kriteria : Kinerja > Melaksanakan Tugas secara professional \& bertanggung jawab.

6) Nilai bobot alternatif strategis berdasarkan kriteria-sub kriteria : Kinerja > Melaksanakan Penilaian yg valid \& bermakna.

7) Nilai bobot alternatif strategis berdasarkan kriteria-sub kriteria : Kinerja > Melakukan pengembangan Diri.

8) Nilai bobot alternatif strategis berdasarkan kriteria-sub kriteria : Karakter > Memiliki keyakinan Tauhid yg kuat \& keinginan untuk sempurna.

9) Nilai bobot alternatif strategis berdasarkan kriteria-sub kriteria : Karakter > Memiliki ketaatan beragama \& keteraturan yg tinggi.

10) Nilai bobot alternatif strategis berdasarkan kriteria-sub kriteria : Karakter > Memiliki akhlak \& keteladanan yg baik.

11) Nilai bobot alternatif strategis berdasarkan kriteria-sub kriteria : Karakter > Memiliki budaya belajar.
12) Nilai bobot alternatif strategis berdasarkan kriteria-sub kriteria : Karakter > Memiliki Hubungan Interpersonal yg baik.

Berikut ini disajikan nilai bobot prioritas yang diurutkan dari prioritas tertinggi ke prioritas terendah berdasarkan kriteria.

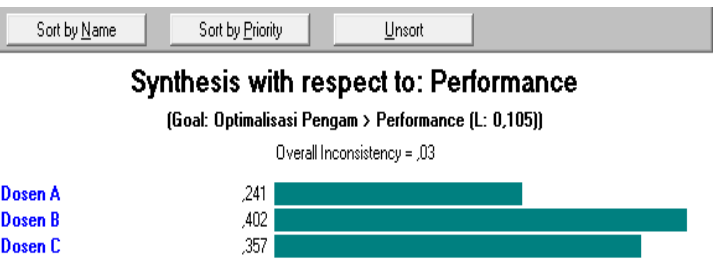

\section{Gambar 4-6 Nilai Bobot Prioritas Alternatif Strategis berdasarkan Performance}

Berdasarkan gambar 4-6 bahwa persepsi responden ahli untuk kriteria Performance, diperoleh bahwa alternatif strategis Dosen B dengan nilai bobot 0,402 atau sebanding dengan $40,2 \%$ memiliki prioritas utama/tertinggi sebagai Dosen berpenampilan/performance terbaik, yang diikuti dengan alternatif Dosen $\mathrm{C}$ dengan bobot $35,7 \%$, dan Dosen A dengan bobot $24,1 \%$ dengan prioritas terendah.

\begin{tabular}{|c|c|c|}
\hline Sort by Name & Sort by Prionity & Unsoort \\
\hline \multirow{3}{*}{\multicolumn{3}{|c|}{$\begin{array}{l}\text { Synthesis with respect to: Kinerja } \\
\text { [Goal: Optimalisasi Pengam > Kinerja (L: } 0,637) \text { ) }\end{array}$}} \\
\hline & & \\
\hline & & \\
\hline Dosen A & .245 & \\
\hline Dosen B & .428 & \\
\hline Dosen C & 327 & \\
\hline
\end{tabular}

\section{Gambar 4-7 Nilai Bobot Prioritas Alternatif Strategis berdasarkan Kinerja}

Berdasarkan gambar 4-7 bahwa persepsi responden ahli untuk kriteria Kinerja, diperoleh bahwa alternatif strategis Dosen $B$ dengan nilai bobot 0,428 atau sebanding dengan $42,8 \%$ memiliki prioritas utama/tertinggi sebagai Dosen berkinerja terbaik, kemudian diikuti dengan alternatif Dosen $C$ dengan nilai bobot 0,327 atau sebanding dengan $32,7 \%$, dan Dosen A dengan nilai bobot 0,245 atau sebanding dengan $24,5 \%$ dengan prioritas terendah.

\begin{tabular}{|c|c|c|}
\hline Sort by Name & Sort by Priority & Unsoot \\
\hline \multicolumn{3}{|c|}{$\begin{array}{l}\text { Synthesis with respect to: Karakter } \\
\text { [Goal: Optimalisasi Pengam > Karakter (L: 0,258)] }\end{array}$} \\
\hline \multicolumn{3}{|c|}{ Overall Inconsistency = 06} \\
\hline Dosen A & 188 & \\
\hline Dosen B & .521 & \\
\hline Dosen C & .291 & \\
\hline
\end{tabular}

Gambar 4-8 Nilai Bobot Prioritas Alternatif Strategis berdasarkan Karakter 
Berdasarkan gambar 4-8 bahwa persepsi responden ahli untuk kriteria Kinerja, diperoleh bahwa alternatif strategis Dosen $\mathrm{B}$ dengan nilai bobot 0,521 atau sebanding dengan $52,1 \%$ memiliki prioritas utama/tertinggi sebagai Dosen berkinerja terbaik, kemudian diikuti dengan alternatif Dosen $C$ dengan nilai bobot 0,291 atau sebanding dengan $29,1 \%$, dan Dosen $A$ dengan nilai bobot 0,188 atau sebanding dengan $18,8 \%$ dengan prioritas terendah.

\subsection{Landasan Alternatif Strategis Secara} Global yang Menjadi Prioritas Pendukung Keputusan dalam Penilaian Kinerja Dosen.

Penelitian ini dilakukan untuk menentukan bobot prioritas di antara kriteria yang sebelumnya ditetapkan dan elemen yang paling mempengaruhi sasaran pendukung keputusan melalui FGD, begitu pula dengan bobot prioritas sub kriteria yang memiliki keterkaitan erat dengan kriteria. Dan pada akhir hipotesa diperoleh bobot alternatif strategis yang dapat di jadikan acuan dalam penilaian kinerja dosen dan diduga bahwa alternatif strategis Dosen B merupakan prioritas alternatif utama yang dipilih oleh responden ahli.

Setelah melalui proses pengisian kuesioner oleh beberapa responden ahli, dan melalui perhitungan geometris penggabungan data responden diperoleh nilai bobot alternatif seperti yang disajikan pada grafik berikut:

\begin{tabular}{|c|c|c|}
\hline Sort by 트ome & Sort by Elioitity & Unsoort \\
\hline \multicolumn{3}{|c|}{ Synthesis with respect to: } \\
\hline \multicolumn{3}{|c|}{ Goal: Optimalisasi Pengambilan Keputusan Penilaian Kineria Dosen } \\
\hline \multicolumn{3}{|c|}{ Overall Inconsistency =, 05} \\
\hline Dosen A & 230 & \\
\hline Dosen B & .448 & \\
\hline Dosen C & 322 & \\
\hline
\end{tabular}

Gambar 4-9 Nilai Bobot Global Prioritas Alternatif Strategis berdasarkan Sasaran Penilaian Kinerja Dosen

Berdasarkan hasil pengolahan data responden ahli diperoleh bahwa prioritas utama atau tertinggi alternatif strategis pengambilan keputusan dalam penilaian kinerja dosen adalah Dosen $B$ dengan nilai bobot 0,448 atau sebanding dengan $44,8 \%$ dari total alternatif yang ditetapkan. Kemudian peringkat prioritas alternatif berikutnya adalah Dosen C (nilai bobot 32,2\%), dan peringkat prioritas terendah adalah Dosen A (nilai bobot $23 \%)$.

Persepsi strategis ini memberikan implikasi bahwa pemilihan Dosen B sebagai Dosen dengan kinerja terbaik telah sejalan dan sesuai dengan mayoritas jawaban para responden berdasarkan kepada kriteria, sub kriteria dan alternatif yang di pilih oleh para responden.

\subsection{Inconsistency Ratio (CR)}

Inconsistency ratio atau rasio inkonsistensi data responden ahli merupakan parameter yang digunakan untuk memeriksa apakah perbandingan berpasangan telah dilakukan dengan konsekuen atau tidak. Rasio inkonsistensi data dianggap baik jika nilai CR-nya $\leq 0.1$.

Dari grafik-grafik diatas dapat disimpulkan bahwa perbandingan berpasangan yang diberikan responden ahli memiliki nilai rasio inkonsistensi yang lebih kecil dari 0,1 sebagai batas maksimum nilai rasio inkonsistensi. Dengan demikian hasil perhitungan geometrik gabungan data responden cukup konsisten.

\section{KESIMPULAN} adalah :

Kesimpulan yang didapat dari penelitian ini

1) Keluaran dari penelitian ini adalah peringkat prioritas alternatif strategis yang dipilih dalam menentukan dosen dengan kinerja terbaik. Hal ini dibuktikan dengan nilai bobot prioritas utama pada alternatif pilihan dosen $B$ dengan bobot sebesar 0,448 atau sebanding dengan $44,8 \%$ dari total alternatif yang ada.

2) Diperoleh gambaran analisa dari tingkat pengaruh masing-masing kriteria terhadap sub kriteria, dan tingkat pengaruh sub kriteria terhadap alternatif yang diberikan.

3) Dalam penentuan atribut sub kiteria untuk masing-masing kriteria didapat hasil bahwa dari 12 (dua belas) usulan atribut sub kriteria yaitu Penampilan Fisik(Penataan Diri), Berbahasa dan Berkomunikasi, Kehadiran \& Keberadaan di Tempat Tugas, Administrasi \& Persiapan Tugas, Melaksanakan Tugas secara professional \& bertanggung jawab, Melaksanakan Penilaian yg valid \& bermakna, Melakukan pengembangan Diri, Memiliki keyakinan Tauhid yg kuat \& keinginan untuk sempurna, Memiliki ketaatan beragama \& keteraturan yg tinggi, Memiliki akhlak \& keteladanan yg baik, dan Memiliki budaya belajar, Memiliki Hubungan Interpersonal yg baik. Sehingga dapat ditarik kesimpulan bahwa sub-sub kriteria diatas dapat dijadikan acuan dalam menentukan penilaian kinerja dosen.

4) Berdasarkan hasil pengolahandata dengan menggunakan pendekatan AHP (Analytical Hierarchy Process), didapat informasi bahwa kriteria yang mendapat prioritas utama adalah kriteria Kinerja dengan nilai bobot sebesar 0,637 atau sebanding dengan $63,7 \%$ dari total kriteria. Selain itu didapat pula subsub kriteria yang mendapat prioritas utama dalam penilaian kinerja dosen diantaranya adalah sub kriteria Kehadiran dan keberadaan di tempat tugas (nilai bobot 0,637 atau setara dengan $63,7 \%$ ), sub kriteria Melaksanakan tugas secara profesional dan bertanggung jawab (nilai bobot 0,573 atau sebanding dengan $57,3 \%$ ) dari total sub kriteria yang ada, kemudian sub-sub kriteria lainnya yang mendapat prioritas utama adalah memiliki akhlak dan keteladanan yang baik dengan mendapat nilai bobot sebesar 0,536 atau sebanding dengan 53,6 \% dari total sub kriteria yang ada. Dengan demikian 
dapat disimpulkan bahwa kriteria dan sub kriteria diatas dapat dijadikan acuan dalam penilaian kinerja dosen.

5) Pengolahan data dilakukan dengan pendekatan AHP, dikarenakan keunggulan yang dimiliki teknik analisa ini, yaitu kesatuan model tunggal yang mudah dimengerti, mampu memecahkan persoalan yang komplek, dapat menangani saling ketergantungan elemen-elemen dalam sistem dan tidak memaksakan pemikiran yang linear, serta masih banyak keunggulan lainnya.

\section{DAFTAR PUSTAKA}

[DYAH 2008] Wulandari, Dyah Asrining, Strategi IT Disaster Recovery Plan Pada Core Banking System dengan Pendekatan Analytical Hierarchy Process, Studi Kasus : PT. Bank Mega Tbk. Tesis di Magister IImu Komputer Universitas Budi Luhur Jakarta, 2008
[ERIKSON 2008] Ferry, Erikson S. Sinaga, Strategi Process Migrasi Proprietary Software Ke Open Source Software Di Perusahaan Dengan Pendekatan Analytical Hierarchy Process (AHP), Studi Kasus : SGU, Tangerang. Tesis di Magister Ilmu Komputer Universitas Budi Luhur Jakarta, 2008

[MARIMIN 2004] Marimin, Teknik dan Aplikasi Pengambilan Keputusan Kriteria Majemuk, IPB Press Bogor, 2004

[RAHMA 2009] Ningrum, Rahma Farah, Jurnal IImiah "Telematika MKOM", Universitas Budi Luhur, Jakarta, 2009

[Saaty 1994] Saaty, T.L., 1994, Fundamentals of Decision Making and Priority Theory with the Analytic Hierarchy Process, RWS Publications, Pittsburgh PA., 1994. 